\title{
Analysis Of Project Success Inhibition Factors
}

\author{
Zulyaden*, Rinaldy \\ Faculty of Engineering, Universitas Teuku Umar, Meulaboh, Aceh, Indonesia \\ *Corresponding author E-mail: zulyaden@utu.ac.id
}

\begin{abstract}
In the implementation of activities we often find what is called a project. The project is an activity that must be completed in accordance with the specified target and time, so that the project can be regarded as a success in project implementation. One of the projects in question is the construction project. Construction projects in their implementation we often encounter various kinds of problems that arise from the elements involved in them, so this can hamper the success of a project that is being implemented. One problem that arises from the contractor factor and contract specification. The purpose of this study is to find out one of the main inhibiting factors in the successful implementation of construction projects in Aceh Province. Classification of construction services for respondents is all construction services from the middle class (M) to large classes (B). The data obtained the total population of construction services as many as 508 contactors from observations of projects that have been completed from 2010-2015 with funds from the Aceh Budget (APBA). By using the Slovin formula a total sample of 84 contractors was found. The method used in this study is a combined method, namely qualitative and quantitative methods through questionnaires. The independent variables reviewed are the contractor factor and the contract specification factor while the dependent variable is the success of the project. For statistical analysis the data process is done by using validity and reliability tests, while analyzing the data is done by using multiple linear regression with the help of Product Solution and Service Statistics (SPSS) version 22. The results of the study indicate that the contractor factor is one of the main inhibiting factors in the successful implementation of the project in Aceh Province.
\end{abstract}

Keywords: Problem, success, project, contractor, project conditions

\section{Introduction}

Implementation of construction projects wherever their activities certainly involve all the elements involved in it, to guarantee the success of a project in accordance with the expected objectives. Projects are a series of activities carried out only once and are generally short term [1]. The expected goal of implementing the project is that the project can be completed on time, the quality of the project is fulfilled and the project implementation does not exceed the stipulated budget [2]. This success can absolutely be produced if all the elements can interact with each other. Interactions in question include working together, coordinating and communicating. In the implementation of the project for its smoothness it also requires an organization [3], which involves interaction between the elements of the project (stakeholders), that is, the project owner, contactor, subcontractor and project consultant.

A project will be hampered in its implementation and far from success if there are disputes or problems between the elements involved in it. Problems that occur will interfere and hinder the efficiency and productivity in project implementation and these problems must be immediately addressed and resolved properly in the shortest possible time in order to achieve the expected results. One of the factors causing the problem as a barrier to the success of construction projects in Aceh Province is the contractor factor and the contract specification factor. In solving problems that occur, an organization involved in project implementation requires effective management to manage the problem, one of which is by identifying, and analyzing the causes of problems / conflicts [4], so that problems that occur can be handled appropriately, quickly and both to achieve the objectives and results of project implementation as expected.

In construction implementation, problems that often arise are unclear authority and responsibility, design and specification errors, personnel placement that is not in accordance with their expertise, inaccurate cost estimates, equipment and material delays, and lack of approaches to deal with the problem [ 5] Other research shows there are four types of potential problems in implementing construction projects, namely problems due to technical factors, problems due to organizational factors, problems due to schedule factors, and problems due to resource factors. However, this problem has a frequency that is low enough to occur [6]. The purpose of this study is to find out one of the main inhibiting factors in the successful implementation of construction projects in Aceh Province. 


\section{Methods}

This study uses a combined method (mixed method), a method that combines qualitative and quantitative approaches. Qualitative methods are used to get respondents' perceptions in words, from the Likert scale used in the questionnaire. In this case the form of the word in question is starting from very no effect, no effect, less influential, influential, and very influential. Quantitative methods are used to get numbers on perceptions obtained from respondents. In this case the number in question is the respondent's answer score starting from $1,2,3,4$ and 5, which is then analyzed to obtain R count, Cronbach Alpha, and the mean value.

\subsection{Test Validity}

Validity test used to measure the validity or validity of an instrument in this case is a questionnaire [7]. This validity test can be formulated as follows.

$$
\mathrm{r}_{\mathrm{xy}}=\frac{N \sum X Y-\left(\sum X\right)\left(\sum Y\right)}{\sqrt{\left\{N \sum X^{2}-\left(\sum X\right)^{2}\right\}\left\{N \sum Y^{2}-\left(\sum Y\right)^{2}\right\}}}
$$

Where:

rxy = correlation coefficient between variables $\mathrm{X}$ and $\mathrm{Y}$;

$\sum X=$ Number of scores obtained from respondents who were tested;

$\sum Y=$ Total score of all items of all respondents tested; and

$\mathrm{N} \quad=$ Number of respondents.

The criteria for evaluating the validity test are if $\mathrm{R}$ count $>\mathrm{R}$ table then the questionnaire question items are valid, and vice versa if $\mathrm{R}$ count $<\mathrm{R}$ table then the questionnaire question items are invalid.

\subsection{Reliability Test}

The instrument is said to be reliable if the instrument can consistently bring up the same results every time a measurement is made [7] . This reliability test can be formulated as follows.

ri $\quad=\left[\frac{k}{k-1}\right]\left[1-\frac{\sum \sigma b^{2}}{\sigma t^{2}}\right]$

Where:

ri $\quad=$ Instrument reliability;

$\mathrm{k} \quad=$ Number of questions;

$\sum \sigma b^{2}=$ Number of item variants; and

$\sigma t^{2}=$ Total variance.

The formula for item variance and total variance is as follows.

$\sigma b^{2}=\frac{\sum x^{2}-\frac{\left(\sum x^{2}\right)}{N}}{N}$

$\sigma t^{2}=\frac{\text { the sum of the squares of the total score }-\frac{\text { the sum of the squares of the total score }}{N}}{N}$

Where:

$\Sigma \times 2=$ Number of squares of variance per item; and

$\mathrm{N} \quad=$ Many respondents.

The criterion for evaluating the reliability test is that if Cronbach Alpha $>0.6$ then the variable in the questionnaire is reliable, and vice versa if Cronbach Alpha $<0.6$ then the variable in the questionnaire is not reliable [8].

\subsection{Descriptive Analysis}

Descriptive analysis is a statistic that serves to describe or give a description of the object under study through sample data or population as it is, without conducting analysis and making conclusions that are applicable to the public [9]. In this descriptive statistic, methods for presenting data with regular tables and frequency distributions, line and bar graphs, pie charts, pictograms, group explanations through 
mode, median, mean, and group variation through standard ranges and deviations will be presented. The mean can be formulated as follows.

$\mathrm{Me}=\frac{\sum x_{i}}{n}$

Where:

Me = Mean (average);

$\sum \quad=$ Sigma (number);

$\mathrm{Xi} \quad=$ value of $\mathrm{x}$ to $\mathrm{i}$ to $\mathrm{n}$; and

$\mathrm{n} \quad=$ Number of respondents [10].

\section{Results And Discussion}

\subsection{Test Validity}

Validity test is used to determine the validity of an item statement on the questionnaire given to respondents. Test criteria if the value of $\mathrm{R}$ count $>\mathrm{R}$ table, then the statement item is valid, conversely if the value of $\mathrm{R}$ count $<\mathrm{R}$ table, then the statement item is invalid. The results of validity tests that have been processed through SPSS software are presented in Table 2.

Table 1 Test Validity

\begin{tabular}{|c|c|c|c|c|c|}
\hline No. & Variable & Statement Item & $\mathrm{R}_{\text {count }}$ & $\mathrm{R}_{\text {table }}$ & Information \\
\hline \multirow[t]{19}{*}{1} & \multirow[t]{19}{*}{ Contractor factor $\left(\mathrm{X}_{1}\right)$} & $\mathrm{X}_{1.1}-\mathrm{X}_{1}$ & 0,903 & 0,212 & Valid \\
\hline & & $\mathrm{X}_{1.2}-\mathrm{X}_{1}$ & 0,865 & 0,212 & Valid \\
\hline & & $\mathrm{X}_{1.3}-\mathrm{X}_{1}$ & 0,937 & 0,212 & Valid \\
\hline & & $\mathrm{X}_{1.4}-\mathrm{X}_{1}$ & 0,758 & 0,212 & Valid \\
\hline & & $\mathrm{X}_{1.5}-\mathrm{X}_{1}$ & 0,810 & 0,212 & Valid \\
\hline & & $\mathrm{X}_{1.6}-\mathrm{X}_{1}$ & 0,866 & 0,212 & Valid \\
\hline & & $X_{1.7}-X_{1}$ & 0,898 & 0,212 & Valid \\
\hline & & $\mathrm{X}_{1.8}-\mathrm{X}_{1}$ & 0,887 & 0,212 & Valid \\
\hline & & $\mathrm{X}_{1.9}-\mathrm{X}_{1}$ & 0,495 & 0,212 & Valid \\
\hline & & $X_{1.10}-X_{1}$ & 0,618 & 0,212 & Valid \\
\hline & & $\mathrm{X}_{1.11}-\mathrm{X}_{1}$ & 0,493 & 0,212 & Valid \\
\hline & & $\mathrm{X}_{1.12}-\mathrm{X}_{1}$ & 0,858 & 0,212 & Valid \\
\hline & & $\mathrm{X}_{1.13}-\mathrm{X}_{1}$ & 0,847 & 0,212 & Valid \\
\hline & & $\mathrm{X}_{1.14}-\mathrm{X}_{1}$ & 0,933 & 0,212 & Valid \\
\hline & & $X_{1.15}-X_{1}$ & 0,775 & 0,212 & Valid \\
\hline & & $\mathrm{X}_{1.16}-\mathrm{X}_{1}$ & 0,817 & 0,212 & Valid \\
\hline & & $\mathrm{X}_{1.17}-\mathrm{X}_{1}$ & 0,867 & 0,212 & Valid \\
\hline & & $\mathrm{X}_{1.18}-\mathrm{X}_{1}$ & 0,902 & 0,212 & Valid \\
\hline & & $\mathrm{X}_{1.19}-\mathrm{X}_{1}$ & 0,889 & 0,212 & Valid \\
\hline \multirow[t]{16}{*}{2} & \multirow{16}{*}{$\begin{array}{l}\text { Contract factors and } \\
\text { specifications }\left(\mathrm{X}_{2}\right)\end{array}$} & $\mathrm{X}_{2.1}-\mathrm{X}_{2}$ & 0,917 & 0,212 & Valid \\
\hline & & $\mathrm{X}_{2.2}-\mathrm{X}_{2}$ & 0,901 & 0,212 & Valid \\
\hline & & $\mathrm{X}_{2.3}-\mathrm{X}_{2}$ & 0,903 & 0,212 & Valid \\
\hline & & $\mathrm{X}_{2.4}-\mathrm{X}_{2}$ & 0,841 & 0,212 & Valid \\
\hline & & $\mathrm{X}_{2.5}-\mathrm{X}_{2}$ & 0,940 & 0,212 & Valid \\
\hline & & $\mathrm{X}_{2.6}-\mathrm{X}_{2}$ & 0,772 & 0,212 & Valid \\
\hline & & $X_{2.7}-X_{2}$ & 0,857 & 0,212 & Valid \\
\hline & & $\mathrm{X}_{2.8}-\mathrm{X}_{2}$ & 0,824 & 0,212 & Valid \\
\hline & & $\mathrm{X}_{2.9}-\mathrm{X}_{2}$ & 0,935 & 0,212 & Valid \\
\hline & & $\mathrm{X}_{2.10}-\mathrm{X}_{2}$ & 0,919 & 0,212 & Valid \\
\hline & & $\mathrm{X}_{2.11}-\mathrm{X}_{2}$ & 0,485 & 0,212 & Valid \\
\hline & & $\mathrm{X}_{2.12}-\mathrm{X}_{2}$ & 0,590 & 0,212 & Valid \\
\hline & & $\mathrm{X}_{2.13}-\mathrm{X}_{2}$ & 0,438 & 0,212 & Valid \\
\hline & & $\mathrm{X}_{2.14}-\mathrm{X}_{2}$ & 0,944 & 0,212 & Valid \\
\hline & & $\mathrm{X}_{2.15}-\mathrm{X}_{2}$ & 0,767 & 0,212 & Valid \\
\hline & & $\mathrm{X}_{2.16}-\mathrm{X}_{2}$ & 0,858 & 0,212 & Valid \\
\hline \multirow[t]{5}{*}{3} & \multirow[t]{5}{*}{ Project success (Y) } & $\mathrm{Y}_{1}-\mathrm{Y}$ & 0,916 & 0,212 & Valid \\
\hline & & $\mathrm{Y}_{2}-\mathrm{Y}$ & 0,920 & 0,212 & Valid \\
\hline & & $Y_{3}-Y$ & 0,971 & 0,212 & Valid \\
\hline & & $Y_{4}-Y$ & 0,882 & 0,212 & Valid \\
\hline & & $Y_{5}-Y$ & 0,929 & 0,212 & Valid \\
\hline
\end{tabular}




\begin{tabular}{cccc}
\hline$Y_{6}-\mathrm{Y}$ & 0,800 & 0,212 & Valid \\
\hline $\mathrm{Y}_{7}-\mathrm{Y}$ & 0,837 & 0,212 & Valid \\
\hline $\mathrm{Y}_{8}-\mathrm{Y}$ & 0,884 & 0,212 & Valid \\
\hline $\mathrm{Y}_{9}-\mathrm{Y}$ & 0,949 & 0,212 & Valid \\
\hline $\mathrm{Y}_{10}-\mathrm{Y}$ & 0,927 & 0,212 & Valid \\
\hline $\mathrm{Y}_{11}-\mathrm{Y}$ & 0,370 & 0,212 & Valid \\
\hline $\mathrm{Y}_{12}-\mathrm{Y}$ & 0,578 & 0,212 & Valid \\
\hline $\mathrm{Y}_{13}-\mathrm{Y}$ & 0,390 & 0,212 & Valid \\
\hline
\end{tabular}

The table above shows that all statement items studied have a value of $\mathrm{R}$ count $>\mathrm{R}$ table. Thus the validity test conducted on all statements on the questionnaire is all valid, so that it can proceed with the reliability test.

\subsection{Reliability Test}

The reliability test is used to determine whether a variable in the questionnaire given to the respondent is reliable or not. The criteria for testing this reliability test if the Cronbach Alpha value on a variable > 0.6 then the reliable variable, and the variable is not reliable if the Cronbach Alpha value on the variable is < 0.6. The reliability test results that have been processed through SPSS software are summarized in Table 2

Table 2 Reliability Tests

\begin{tabular}{clcc}
\hline No. & \multicolumn{1}{c}{ Variable } & Cronbach Alpha $>0,6$ & Information \\
\hline 1 & Contractor factor $\left(\mathrm{X}_{1}\right)$ & 0,972 & Reliable \\
\hline 2 & Contract factors and specifications $\left(\mathrm{X}_{2}\right)$ & 0,966 & Reliable \\
\hline 3 & Project success $(\mathrm{Y})$ & 0,957 & Reliable \\
\hline
\end{tabular}

The table above shows that all variables on the questionnaire have a Cronbach Alpha > 0.6. Therefore, the reliability tests conducted on all variables are all reliable, so it can be continued in data analysis.

\subsection{Descriptive Analysis}

Descriptive analysis is used to determine contractors' perceptions about one of the main factors as a cause of conflict in the realization of construction project activities. Following are the results of each factor summarized in table 3 using SPSS version 22.

Table 3 Mean Factors Causing Conflict

\begin{tabular}{|c|c|c|c|}
\hline No. & Variable & Mean & the ranking \\
\hline 1 & Contractor factor $\left(\mathrm{X}_{1}\right)$ & 4,239 & 1 \\
\hline 2 & Contract factors and specifications $\left(\mathrm{X}_{2}\right)$ & 4,138 & 2 \\
\hline
\end{tabular}

The table above shows the results with a mean value that is not much difference between the two factors as the main inhibiting factor in the success of construction projects in Aceh Province, namely for the contractor factor the calculation result is 4.239 and the contract specification factor with the calculation result 4.138. This means that based on the contractor's perception, one of the main factors hampering the success of the project in its implementation in Aceh Province with the highest calculation result is the contractor factor itself with a value of 4.239 and a difference of value of 0.101 from the contract and specification factors. The contractor factor has 19 indicators in the assessment, namely the lack of contractor management, supervision and coordination, work delays, failure to plan and implement changes in work, failure to understand the price of work or bid correctly, lack of understanding of the agreements contained in the contract, unwillingness to ask for clarification , scheduling work (scheduling) that is not good, start the project implementation work, before the implementation document (contract) is finished processing, the implementation of the work begins without a pattern of work process sequences, time programs and critical lines (time schedule), site engineer or field coordinator who is not mastering the whole process, contractor's mistakes in estimating work costs, the contractor does not read and understand the documents properly, the planning is not good from the contractor so that it cannot fulfill the planned schedule, there is no morale in the team, the contractor cannot akap or experience, disobeying orders, misuse of materials, skilled personnel and methods of implementation, changes in the scope of work outside the contract, lack of experience handling the project from the contractor.

For solutions that can be applied include creating good contractor management, supervision and coordination, optimal time to start work, having the ability to plan and implement job changes, understand the value of work or offer correctly, understand the agreements in the contract, want to ask questions to ask for clarification, good job scheduling management, start the project implementation work after the implementation documents (contracts) are finished processing, work implementation with regular work process stages, time programs and critical lines (time schedule), site engineer or field coordinator controls the whole process, the contractor is able to estimate the cost of work, the contractor knows and understands the documents properly, good planning from the contractor so that it can meet the planned schedule, have a working spirit in the team, a reliable or experienced contractor, obey orders, appropriate in using materials, skilled personnel and methods of implementation, working in accordance with the scope of work in the contract, and experienced in handling the project from the contractor.

\section{Conclusion}

In the implementation of construction projects in Aceh Province, one of the main factors which is an obstacle to the success of the project is the contractor factor. The contractor factor has a value of 0,101 higher than the contract specification factor. 


\section{Acknowledgement}

Acknowledgments the authors convey to all parties who have contributed to the research until the completion of this article was made.

\section{References}

[1] Ervianto, WI 2004, Teori Aplikasi Manajemen Proyek Konstruksi, Salemba Empat, Yogyakarta.

[2] Syah, M 2004, Kiat Manajer yang Sukses, Binapura Aksara, Jakarta.

[3] Dipohusodo, 1995, Manajemen Proyek \& Konstruksi Jilid 2, Kanasius, Yogyakarta.

[4] Ock, JH dan Han, SH 2003, Lesson Learned form Rigid Conflict Resolution in an Organization: Construction Conflict Case Study, Journal of Management in Engineering, April 2003.

[5] Susila, H., 2012, Faktor-faktor Penyebab Konflik dalam Pelaksanaan Proyek Konstruksi, Jurnal Teknik Sipil dan Arsitektur, Universitas Tunas Pembangunan Surakarta, Volume 11. No. 15, Maret 2012, ISSN: 2301-668X.

[6] Aderiani, R., Tantyonimpuno, S., dan Adi, W, J, T., 2005, Identifikasi Konflik yang Terjadi pada Pelaksanaan Proyek Konstruksi Gedung, Prosiding Seminar Nasional Manajemen Teknologi I, Program Studi Magister Manejemen Teknologi Institut Teknologi Sepuluh Nopember, ISBN: 979-99302-0-0.

[7] Priyatno, D 2010, Teknik Mudah dan Cepat Melakukan Analisis Data Penelitian dengan SPSS dan Tanya Jawab Ujian Pendadaran, Gaya Media, Yogyakarta.

[8] Ferdinand, A., 2006, Metode Penelitian Manajemen, Universitas Diponegoro, Semarang.

[9] Narbuko, C dan Achmadi, A 2004, Metodelogi Penelitian, Bumi Aksara, Jakarta.

[10] Sugiyono, 2015, Statistik Nonparametris untuk Penelitian, Alfabeta, Bandung. 